\title{
Research
}

\section{Tools for Resilience Management: Multidisciplinary Development of State-and-Transition Models for Northwest Colorado}

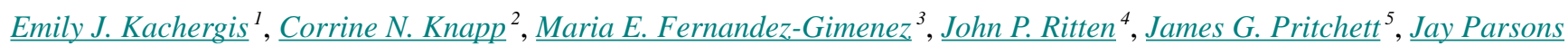 \\ ${ }^{6}$, Willow Hibbs ${ }^{7}$ and Roy Roath $^{3}$
}

\begin{abstract}
Building models is an important way of integrating knowledge. Testing and updating models of social-ecological systems can inform management decisions and, ultimately, improve resilience. We report on the outcomes of a six-year, multidisciplinary model development process in the sagebrush steppe, USA. We focused on creating state-and-transition models (STMs), conceptual models of ecosystem change that represent nonlinear dynamics and are being adopted worldwide as tools for managing ecosystems. STM development occurred in four steps with four distinct sets of models: (1) local knowledge elicitation using semistructured interviews; (2) ecological data collection using an observational study; (3) model integration using participatory workshops; and (4) model simplification upon review of the literature by a multidisciplinary team. We found that different knowledge types are ultimately complementary. Many of the benefits of the STM-building process flowed from the knowledge integration steps, including improved communication, identification of uncertainties, and production of more broadly credible STMs that can be applied in diverse situations. The STM development process also generated hypotheses about sagebrush steppe dynamics that could be tested by future adaptive management and research. We conclude that multidisciplinary development of STMs has great potential for producing credible, useful tools for managing resilience of social-ecological systems. Based on this experience, we outline a streamlined, participatory STM development process that integrates multiple types of knowledge and incorporates adaptive management.
\end{abstract}

Key Words: adaptive management; ecology; ecosystem dynamics; knowledge integration; participatory research; rangeland; sagebrush steppe

\section{INTRODUCTION}

Models are tools that help us see the connections in complex systems, including social-ecological systems. Mental models underlie every individual's interactions with the world (Jones et al. 2011). Understanding each other's mental models is crucial for communicating about social-ecological systems (Abel et al. 1998). Scientists often use written, conceptual models consisting of diagrams, text, and equations to explore and test existing knowledge about a system. Increasingly, these models incorporate multiple types of knowledge (e.g., Knapp et al. 2011a). Testing and updating these models results in an "explicit learning" process that enhances individuals' and society's capacity to respond to environmental stresses such as drought (Roux et al. 2006), ultimately strengthening social-ecological system resilience. Building conceptual system models is a key step in natural resource management, including the adaptive management process (Holling 1978) and resilience-based approaches (Walker et al. 2002). The process of creating and updating models can have a major impact on overall understanding of systems (Jackson et al. 2000, Jones et al. 2011). The purpose of this paper is to share lessons learned from a six-year, multidisciplinary model development process in the sagebrush steppe, USA.
State-and-transition models (STMs; Westoby et al. 1989) are being adopted as a primary tool for understanding and managing the resilience of diverse ecosystems around the world (Briske et al. 2008, Hobbs and Suding 2009, Zweig and Kitchens 2009). These conceptual models describe changes in ecosystems as a series of threshold shifts between alternate states (Westoby et al. 1989, Bestelmeyer et al. 2003, Suding and Hobbs 2009). According to ecological theory, a state is a dynamic regime governed by unique processes (Scheffer 2009), operationalized in STMs as a set of plant communities with "persistent functional and structural attributes associated with a characteristic range of variability" (Briske et al. 2008:361). States are resilient, meaning that they have high capacity for undergoing change while still retaining controls on their structure and function (Holling 1973). Variants of states with similar processes are called communities within a state. Transitions between states occur when one or more of the processes maintaining a state degrade, often triggered by a perturbation from management or disturbance (Stringham et al. 2003, Briske et al. 2008, Scheffer 2009). The result is a loss in resilience and a change to an alternate state with different structure and function (Briske et al. 2008, Scheffer 2009). In the U.S., STMs have become an integral part of

\footnotetext{
${ }^{1}$ Bureau of Land Management, Denver, Colorado, ${ }^{2}$ Alaska Center for Climate and Policy, ${ }^{3}$ Department of Forest and Rangeland Stewardship, Colorado State University, ${ }^{4}$ Department of Agricultural and Applied Economics, University of Wyoming, ${ }^{5}$ Department of Agricultural and Resource Economics, Colorado State University, ${ }^{6}$ Western Center for Integrated Resource Management, Colorado State University, ${ }^{7}$ Wyoming Game and Fish Department and USDANRCS
} 
rangeland management policy under an agreement between the Natural Resources Conservation Service, the Forest Service, and the Bureau of Land Management (USDA 2010). Comparisons of development methods and resulting models are crucial for informing STM development (Knapp et al. 2011b), adaptively managing ecosystems (Walters and Holling 1990), and maintaining social-ecological system resilience (Walker et al. 2002).

Our objectives in this paper are (1) to provide an overview of a six-year, multidisciplinary STM development process and (2) evaluate the relative contributions of different knowledge types to STM development. Our research group has used different combinations of local and expert knowledge, ecological data, and literature review to develop STMs. Our process resulted in four models of sagebrush steppe ecosystem dynamics (Fig. 1). The first three models were intended for land management decision making and were based on ecological data (Kachergis et al. 2012), local and expert knowledge (Knapp and Fernandez-Gimenez 2009), and the integration of the two (Knapp et al. 2011a). The final, simplified model was reduced from the integrated model to serve as the basis for a ranch economic simulation that represents trade-offs among a suite of ecosystem services (Hibbs 2011, Ritten et al. 2011, Pritchett et al. 2012). We use this work as a foundation for discussing the integration of different types of knowledge for developing tools for managing social-ecological system resilience.

Fig. 1. Graphical overview of the multidisciplinary state and transition model development process used for two types of land in the Elkhead Watershed, Colorado, USA.

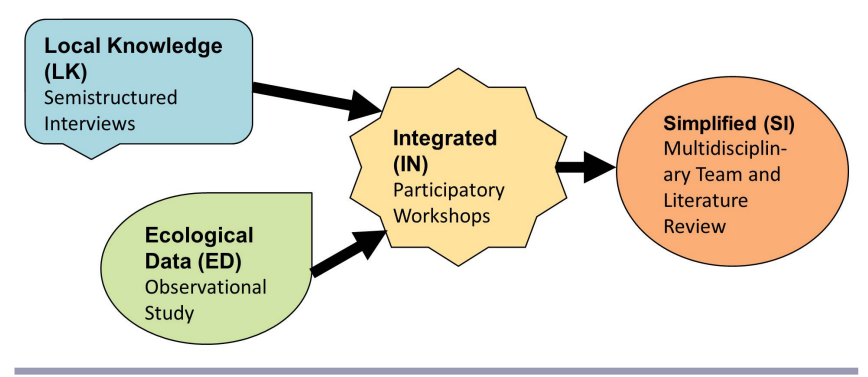

\section{METHODS: FOUR MODEL DEVELOPMENT PROCESSES}

Our goal was to create STMs to inform land management decision making and improve resilience of rangeland socialecological systems. We focused on the Elkhead Watershed, a 60,000-hectare watershed in the sagebrush steppe of northwest Colorado, USA. This area was chosen because ranching is the primary land use, it contains a mix of small and large landowners, and it remains relatively unfragmented. STM development occurred in four steps with four distinct sets of models (Fig. 1): (1) local knowledge elicitation using semistructured interviews; (2) ecological data collection using an observational study; (3) model integration using participatory workshops; and (4) model simplification upon review of the literature by a multidisciplinary team. The multidisciplinary research team included vegetation and wildlife ecologists, human ecologists, and agricultural economists, many of whom had significant agricultural extension experience.

\section{Local knowledge (LK)}

People who interact with ecosystems on a regular basis gain local knowledge that can provide insight about local context (Dewalt 1994), management practices (Flora 1992, Eshuis and Stuiver 2005), and the interconnection between social and ecological systems (Fazey et al. 2006, Peloquin and Berkes 2009, Fairweather 2010). Local knowledge is thought to be an essential ingredient in successful comanagement of natural resources (Fernandez-Gimenez et al. 2007, Plummer and Armitage 2007) and maintaining resilient social-ecological systems (Berkes et al. 2000). The practice of integrating local knowledge in development of ecosystem management tools is gaining acceptance worldwide yet still relatively rare within the U.S. Knapp and Fernandez-Gimenez (2009) adopted Agrawal's (Agrawal 1995) definition of local knowledge as knowledge "integrally linked with the lives of people, always produced in dynamic interactions among humans and between humans and nature, and constantly changing." Knapp and Fernandez-Gimenez (2009) documented rancher knowledge in the Elkhead Watershed using semistructured interviews with 26 local ranchers followed up by 11 field interviews. All interviews were audio-recorded, transcribed, and analyzed using qualitative analysis methods, focusing on four STM components, state, transition, threshold, indicator, as well as ecological processes. These components were compiled into a working STM describing sagebrush steppe vegetation change based on rancher knowledge. The STM was validated by internal comparisons between interviews and a community meeting (Knapp and Fernandez-Gimenez 2009).

\section{Ecological data (ED)}

Some argue that quantitative ecological data is the most reliable basis for modeling ecosystems (Allen-Diaz and Bartolome 1998, Stringham et al. 2003). Because long-term data are not available for many types of land, model building efforts often turn to observational studies comparing areas that have been managed differently (Petersen et al. 2009). Kachergis et al. $(2011,2012)$ conducted an observational study on two different types of land with similar vegetation, soils, and climate (ecological sites) in the Elkhead Watershed: Claypan, characterized by alkali sagebrush (Artemisia arbuscula ssp. longiloba) and clay soils that restrict water infiltration; and Mountain Loam, characterized by mountain big sagebrush (Artemisia tridentata ssp. vaseyana) and loamy soils. They stratified sampling by both soil type and 
management history and described vegetation, soils, and ecological process indicators, including indicators of rangeland health (Pellant et al. 2005) at each plot. Potential alternate states within each ecological site were identified based on similarity in species composition using hierarchical cluster analysis. Nonmetric multidimensional scaling and logistic regression were used to identify unique processes associated with each state and triggers of transitions between states. Although the analyses used to build the models were quantitative, this approach did not provide all of the necessary information for building a complete STM; for example, we observed what management practices current state is associated with, but not how each site transitioned to its current state (path dependency). For this reason, building the ED model relied partly on assumptions and ecological reasoning drawn from other studies. In the example above, it was assumed that all states could transition from the reference state. This process produced two STMs, one each for the Claypan and Mountain Loam ecological sites (Kachergis et al. 2012).

\section{Integrated (IN)}

Integration of information from different sources can provide insights about complex systems at multiple scales (Cash et al. 2006) and ultimately lead to research that is more accurate and relevant for decision making than any individual source (Fortmann and Ballard 2011). The modeling process itself improves communication (Heemskerk et al. 2003), and models based on multiple sources of information may be more credible and useful for all involved. The LK and ED models were integrated through two workshops held in the Elkhead Watershed in 2009 (Knapp et al. 2011a). These workshops were designed to provide many opportunities for small and large group discussions, which are an effective way to facilitate knowledge sharing (Patel et al. 2007). Each workshop agenda went as follows: (1) presentation of STM terminology and the STMs themselves; (2) small-group breakout sessions in which participants evaluated the accuracy and utility of each STM (LK, ED) by writing on a large poster of the model, then shared their critiques with the larger group; (3) large-group modeling session in which participants assembled an integrated STM, using components of the previous STMs as well as new components generated during the group discussions, on a large blank foam-core board; (4) an individual assessment of agreement by placing green or red dots on integrated STM components that each individual strongly agreed or disagreed with; and (5) specific model evaluation forms and an overall workshop evaluation questionnaire. This process also produced two STMs, one each for the Claypan and Mountain Loam ecological sites, which integrated components of the ED and LK models.

\section{Simplified (SI)}

We sought to explore the future economic and ecological costs of different management decisions using the integrated STMs and a quantitative simulation model (Hibbs 2011, Ritten et al.
2011, Pritchett et al. 2012). Computation power required that we reduce the number of states, which we did based on agreement with the literature and frequency of occurrence (unfamiliar or uncommon states were left out). We also designated a state dominated by western wheatgrass that had been identified as a community in the IN because (1) literature suggested that it was a state and (2) the ecological and economic consequences are greater for incorrectly assuming that states are communities (Scheffer 2009). We defined transitions between states based on the IN models, supplemented by the literature where they lacked sufficient specificity about transition mechanisms.

Probabilities of transitions between states were determined through elicitation from experts and combination in the framework of a Bayesian Belief Network (BBN). A BBN is a diagram of nodes and links that models cause-and-effect relationships among variables in a system and provides a transparent way of integrating subjective judgments (McCarthy 2007). The BBNs were based on the STMs for each ecological site, following the guidelines of Cain (2001) and the example of Bashari et al. (2008). We designed a probability elicitation survey following the guidelines of Cain (2001:105) for 'academic 'expert' opinion based on theoretical calculation or best judgment." The elicitation survey was a series of questions about in how many pastures out of 10 an event would occur, given a combination of preceding conditions. For example, participants were asked to tell us "How many pastures out of 10 that hadn't been aerially sprayed or burned in the last 3 years have moderate-high shrub cover?" We used a three-year time step to increase the precision of estimates because sagebrush steppe is a slowlychanging ecosystem. Elicited probabilities were averaged, entered into the Conditional Probability Tables of the BBN (Clemen and Winkler 1999), and validated through detailed interviews with two independent experts. Transitions in the SI models were updated to reflect the transition triggers suggested by this process.

The SI models were further validated through several outreach workshops featuring a ranch simulation game based on the SI models and associated economic modeling (Pritchett et al. 2012). Participants were asked to manage a model ranch where the landscape responded to management and environmental variation according to the SI models.

\section{RESULTING MODELS}

\section{Local knowledge (LK)}

Interviews with local landowners resulted in a model of vegetation change generalized across Elkhead Watershed sagebrush steppe (Knapp and Fernandez-Gimenez 2009). This process identified seven states and three communities (Tables 1 and 2). Four key thresholds, characterized by changes in ecological processes, were identified: (1) weed invasion 
Table 1. States (bold) and communities (plain text) of the Claypan ecological site, northwest Colorado, USA, drawn from a multidisciplinary modeling process (see Fig. 1). Similar states and communities from different modeling steps are on the same line. Many states and communities were identified at multiple modeling steps, and the Simplified model reflects states about which there was the most agreement.

\begin{tabular}{|c|c|c|c|}
\hline Local Knowledge & Ecological Data & Integrated & Simplified \\
\hline Natural sagebrush steppe & Native sagebrush steppe & Native sagebrush steppe & Native sagebrush steppe \\
\hline Native sagebrush steppe & $\begin{array}{l}\text { Alkali sagebrush shrubland with } \\
\text { diverse understory } \\
\text { Alkali sagebrush/bluegrass } \\
\text { shrubland }\end{array}$ & $\begin{array}{l}\text { Alkali sagebrush shrubland with } \\
\text { diverse understory } \\
\text { Alkali sagebrush/bluegrass } \\
\text { shrubland }\end{array}$ & $\begin{array}{l}\text { Alkali sagebrush shrubland with } \\
\text { diverse understory } \\
\text { Alkali sagebrush/bluegrass } \\
\text { shrubland }\end{array}$ \\
\hline Degraded sagebrush steppe & $\begin{array}{l}\text { Alkali sagebrush/western } \\
\text { wheatgrass shrubland }\end{array}$ & $\begin{array}{l}\text { Degraded alkali sagebrush/western } \\
\text { wheatgrass shrubland }\end{array}$ & $\begin{array}{l}\text { Alkali sagebrush/western } \\
\text { wheatgrass shrubland }\end{array}$ \\
\hline \multicolumn{4}{|l|}{ Improved sagebrush steppe } \\
\hline $\begin{array}{l}\text { Chemically managed } \\
\text { grassland }\end{array}$ & Native grassland & $\begin{array}{l}\text { Chemically managed grassland } \\
\text { and } \\
\text { Native grassland }\end{array}$ & Native grassland \\
\hline $\begin{array}{l}\text { Weedy sagebrush steppe } \\
\text { Thick sagebrush steppe }\end{array}$ & & Weedy sagebrush steppe & \\
\hline Cultivated lands & Cultivated lands ${ }^{\dagger}$ & Cultivated lands & \\
\hline \multicolumn{4}{|l|}{ Program lands } \\
\hline Weed monoculture & $\begin{array}{l}\text { Three-tip/mountain big } \\
\text { sagebrush shrubland }\end{array}$ & $\begin{array}{l}\text { Weed (invasive) monoculture } \\
\text { Footnote state: Three-tip/ } \\
\text { mountain big sagebrush } \\
\text { shrubland }\end{array}$ & \\
\hline & $\begin{array}{l}\text { Eroding alkali sagebrush } \\
\text { shrubland }\end{array}$ & $\begin{array}{l}\text { Eroding alkali sagebrush } \\
\text { shrubland }\end{array}$ & $\begin{array}{l}\text { Eroding alkali sagebrush } \\
\text { shrubland }\end{array}$ \\
\hline
\end{tabular}

'Included in model, but did not sample species composition

associated with overgrazing, (2) sagebrush dominance associated with lack of fire, (3) sagebrush absence associated with aerial spraying of herbicides, and (4) cultivating the land. Ranchers at the community meeting generally agreed with the model, but expressed concern about lack of interactions with other vegetation types, a limitation that is inherent to the current structure of STMs.

\section{Ecological data (ED)}

The observational study of lands that had been managed differently resulted in two models for two ecological sites in the Elkhead Watershed, Claypan and Mountain Loam (Kachergis et al. 2012). The Claypan model had seven potential states and the Mountain Loam model had six (Tables 1 and 2; counts exclude cultivated lands). Management practices were associated with many states, but several were also related to variation in soils and topography. Without having yet incorporated evidence of differences in ecological processes in each state (e.g., Stringham et al. 2003) at the time of the knowledge integration workshops, we did not identify thresholds but instead treated each group with significantly different species composition as different states. Some have argued that the burden of proof ought to be on showing alternate states do not exist, given the ecological and economic consequences of a transition (Scheffer 2009). Later analyses of this dataset used the qualitative indicators of rangeland health (Pellant et al. 2005) as evidence of differences in process to differentiate states from communities (Kachergis et al. 2011).

\section{Integrated (IN)}

The workshop-based model integration process created two STMs, one each for Claypan and Mountain Loam (Knapp et al. 2011a). These were considerably more complex than either the LK or ED models. Both models had nine states, and Claypan had three and Mountain Loam had five communities within the reference state, characterized by sagebrush with a diverse understory (Tables 1 and 2). Transitions between states and communities were more numerous and encompassed a greater breadth of management practices and ecosystem components than either the LK or ED models. They also were more specific than either the LK or ED models, including long lists of different types of factors. Despite their complexity, these models were deemed credible by workshop participants. Disagreement and uncertainty were more common surrounding the transitions than the states. Participants 
Table 2. States (bold) and communities (plain text) of the Mountain Loam ecological site, northwest Colorado, USA, drawn from an iterative model building process (see Fig. 1). Similar states and communities from different modeling steps are on the same line. Many states and communities were identified at multiple modeling steps, and the Simplified model reflects states about which there was the most agreement.

\begin{tabular}{|c|c|c|c|}
\hline Local Knowledge & Ecological Data & Integrated & Simplified \\
\hline Natural sagebrush steppe & $\begin{array}{l}\text { Mountain big sagebrush } \\
\text { shrubland with diverse } \\
\text { understory }\end{array}$ & $\begin{array}{l}\text { Mountain big sagebrush } \\
\text { shrubland with diverse } \\
\text { understory } \\
\text { Early seral }\end{array}$ & $\begin{array}{l}\text { Mountain big sagebrush } \\
\text { shrubland with diverse } \\
\text { understory }\end{array}$ \\
\hline Native sagebrush steppe & & $\begin{array}{l}\text { Native sagebrush steppe } \\
\text { Late seral }\end{array}$ & \\
\hline Degraded sagebrush steppe & $\begin{array}{l}\text { Mountain big sagebrush/ } \\
\text { western wheatgrass shrubland }\end{array}$ & $\begin{array}{l}\text { Mountain big sagebrush/western } \\
\text { wheatgrass shrubland }\end{array}$ & $\begin{array}{l}\text { Mountain big sagebrush/ } \\
\text { western wheatgrass shrubland }\end{array}$ \\
\hline Improved sagebrush steppe & & Invaded sagebrush steppe & \\
\hline $\begin{array}{l}\text { Chemically managed } \\
\text { grassland }\end{array}$ & & Intensively managed grassland & \\
\hline Weedy sagebrush steppe & & Weedy sagebrush steppe & \\
\hline Thick sagebrush steppe & $\begin{array}{l}\text { Dense mountain big sagebrush } \\
\text { shrubland } \\
\text { Eroding mountain big } \\
\text { sagebrush shrubland }\end{array}$ & $\begin{array}{l}\text { Dense or eroding mountain big } \\
\text { sagebrush shrubland }\end{array}$ & $\begin{array}{l}\text { Dense or eroding mountain } \\
\text { big sagebrush shrubland }\end{array}$ \\
\hline Cultivated lands & Cultivated lands $s^{\dagger}$ & Cultivated lands & \\
\hline $\begin{array}{l}\text { Conservation Reserve } \\
\text { Program lands }\end{array}$ & Planted grasslands & Planted & \\
\hline Weed monoculture & Snowberry shrubland & $\begin{array}{l}\text { Shrub-dominated } \\
\text { Grass-dominated } \\
\text { Weed monoculture } \\
\text { Snowberry shrubland } \\
\text { Wyethia-dominated }\end{array}$ & \\
\hline
\end{tabular}

Included in model, but did not sample species composition

commented on the complexity of dynamics, that they had not personally observed transitions, and that transition triggers were too vague, e.g., grazing. Some workshop participants expressed concern that these models were oversimplifications.

With the IN model, participants, rather than researchers, were tasked with building an STM that is consistent with the underlying theory. We gave an introductory presentation in each workshop and often redirected conversation back to theoretical issues to ensure that they were well understood. However, we cannot be sure that participants intended for each transition to cross a threshold. Indeed, the large number of states and high probabilities of some transitions raise questions about whether they are truly different states consistent with ecological theory and not just different communities within a given state.

\section{Simplified (SI)}

The research team reduced the Claypan and Mountain Loam models down to simpler versions that could be quantified for incorporation into an economic decision-making tool. The final, simplified models contain elements of all preceding models (Tables 1 and 2; Fig. 2). Claypan had four states, and Mountain Loam had three. Through the process of surveying local ranchers and interviewing experts about transition probabilities in addition to literature review, transition causes and mechanisms became much more precise than with the ED, LK, or IN models, e.g., different amounts and timing of grazing. However, some uncertainty remained, particularly about transitions to and from the sagebrush shrubland states characterized by western wheatgrass on both ecological sites.

The outreach workshops showed that the SI models are credible to a broad audience, including ranchers, other land managers, and rangeland academics (Pritchett et al. 2012). However, several academics expressed concern about the distinction between states and communities in the SI model.

\section{Agreement, disagreement, and uncertainty}

The model building process revealed areas of agreement and disagreement about rangeland ecosystem dynamics in the Elkhead Watershed. We used triangulation, a methodology of 
Fig. 2. Simplified state and transition model of rangeland ecosystem dynamics for the Claypan ecological site, northwest Colorado, USA. Supporting information for model elements came from different parts of the model development process, which are indicated in parentheses. $\mathrm{ED}=$ Ecological data; LK = Local knowledge; IN = Integrated; SI = Simplified.

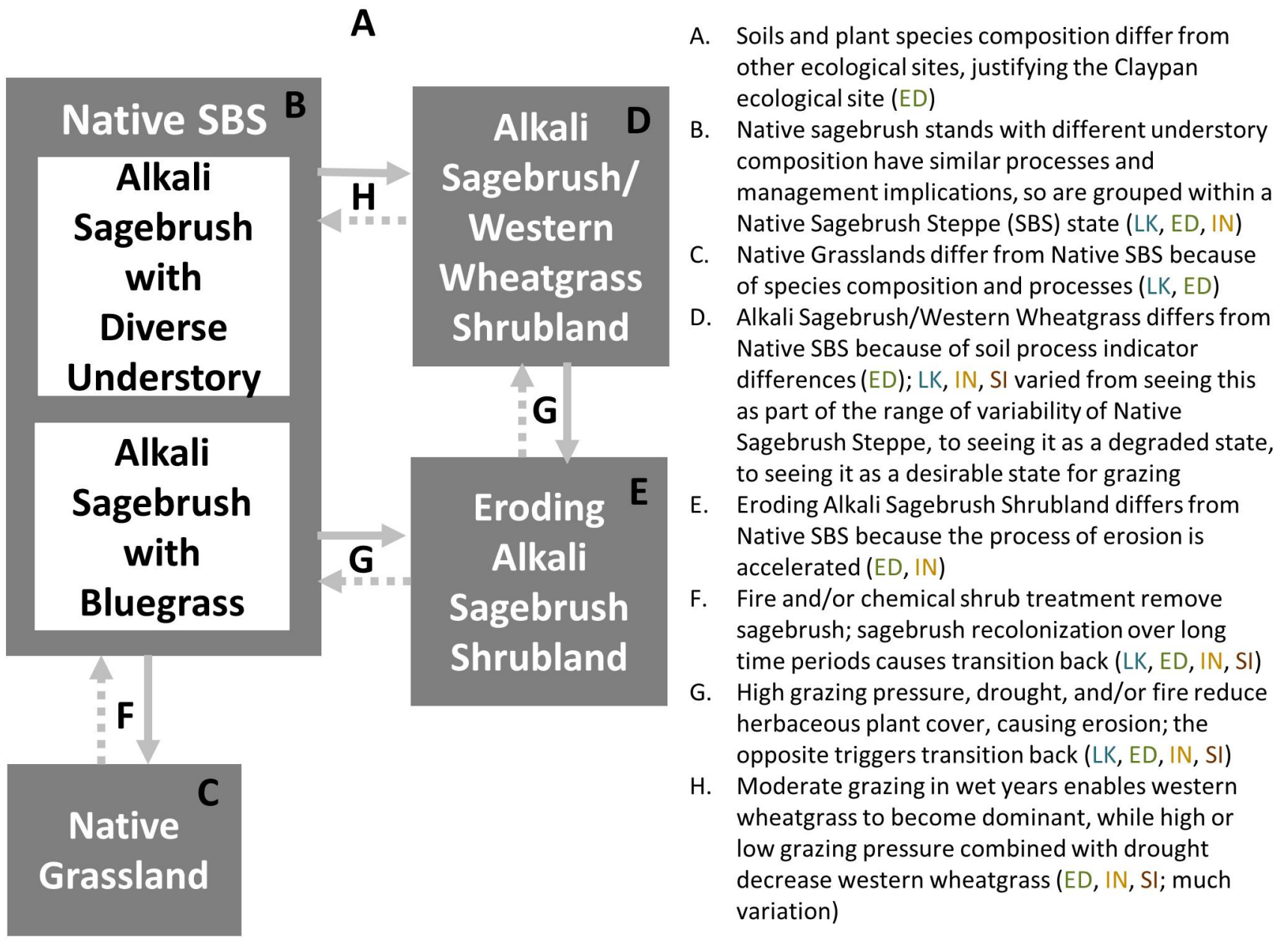

placing knowledge claims in relation to one another, to understand commonality and difference between models resulting from different types of knowledge. Claims with greater support, i.e., similar observations or correspondence between knowledge types, indicate certainty that was gained through the modeling process. A majority of states from the LK and ED models were also present in the IN for both ecological sites (Tables 1 and 2), showing a high amount of agreement among knowledge types. The SI represents the states that were most agreed upon (Tables 1 and 2; Fig. 2). For most of these states, there was broad agreement about the causes of transitions in the IN and SI, despite the fact that LK and ED initially focused on different triggers for transitions (Knapp et al. 2011a).

Disagreements among individuals or among different knowledge types indicated greater uncertainty. Disagreements focused on whether some states were truly alternate states rather than communities, the specific causes of transitions, and whether environmental variation influences transitions. Uncertainty was highest about the states characterized by western wheatgrass on both ecological sites. The literature and differences in dynamic soil properties supported the concept of wheatgrass-dominated states (Cagney et al. 2010, Duniway et al. 2010); however, there was much discussion about whether they were actually communities within the reference states, or variants with more clayey surface soils on each ecological site. Because they were the most common states in the ED models, and given the ecological and economic consequences of transitions (Scheffer 2009), we separated them as states in the SI model. However, variability in the transition causes and probability estimates indicates that uncertainty about this state remains high. 
Table 3. Utility of different sources of knowledge for developing state-and-transition models (STM) for resilience management.

\begin{tabular}{|c|c|c|c|c|}
\hline Type & Strength & Limitation & Output & Application \\
\hline Local Knowledge & $\begin{array}{l}\text { Encompasses a long time } \\
\text { frame and a variety of } \\
\text { management practices/ } \\
\text { disturbances; provides } \\
\text { insights into social } \\
\text { drivers; establishes } \\
\text { vocabulary; improves } \\
\text { communication }\end{array}$ & $\begin{array}{l}\text { No quantitative evidence; } \\
\text { less specific about } \\
\text { biophysical dynamics }\end{array}$ & $\begin{array}{l}\text { STM for a vegetation } \\
\text { type in a region (or, } \\
\text { with field trips, } \\
\text { ecological site) }\end{array}$ & $\begin{array}{l}\text { Planning; rangeland } \\
\text { monitoring, assessment, } \\
\text { and experiments; guiding } \\
\text { further knowledge } \\
\text { gathering }\end{array}$ \\
\hline $\begin{array}{l}\text { Ecological Data } \\
\text { (Observational) }\end{array}$ & $\begin{array}{l}\text { Evidence is quantitative; } \\
\text { provides written record of } \\
\text { a variety of biophysical } \\
\text { indicators }\end{array}$ & $\begin{array}{l}\text { Does not account for } \\
\text { temporal variability; may } \\
\text { miss value-defined states }\end{array}$ & $\begin{array}{l}\text { STM for an ecological } \\
\text { site in a region }\end{array}$ & $\begin{array}{l}\text { Planning; rangeland } \\
\text { monitoring, assessment, } \\
\text { and experiments; guiding } \\
\text { further knowledge } \\
\text { gathering }\end{array}$ \\
\hline Model Integration & $\begin{array}{l}\text { Reconciles different } \\
\text { knowledge sources; } \\
\text { complex; more accurate }\end{array}$ & $\begin{array}{l}\text { Representing areas of } \\
\text { disagreement; complex; } \\
\text { fidelity to STM concepts }\end{array}$ & $\begin{array}{l}\text { Complex STM for an } \\
\text { ecological site, } \\
\text { incorporating more } \\
\text { drivers }\end{array}$ & $\begin{array}{l}\text { Rangeland monitoring, } \\
\text { assessment, and adaptive } \\
\text { management; decision } \\
\text { making; hypotheses for } \\
\text { research }\end{array}$ \\
\hline Simplified & Easier to quantify and use & $\begin{array}{l}\text { Lacks complexity and } \\
\text { nuance of real world }\end{array}$ & $\begin{array}{l}\text { Simple STM for an } \\
\text { ecological site, focused } \\
\text { on the most common/ } \\
\text { important dynamics }\end{array}$ & $\begin{array}{l}\text { Simulation model, } \\
\text { teaching tool }\end{array}$ \\
\hline
\end{tabular}

A second important disagreement was about the weedy sagebrush steppe state, which was identified by land managers in the LK and IN models but not by data in the ED models. Land managers indicated that they perceive and manage these lands differently, but the research team did not feel they had enough evidence from the ED effort or the ecological literature to establish this as an alternate state in the SI model. This suggests that STMs built only on ecological data and theory may not address all of the ecosystem differences that are important to managers.

\section{DISCUSSION}

It is increasingly recognized that developing effective tools to manage resilience in social-ecological systems requires synthesizing information from different sources (Walker et al. 2002, Roux et al. 2006, Raymond et al. 2010, Knapp et al. $2011 b$ ). STMs are vegetation management tools that reflect current scientific understanding of ecosystem resilience (e.g., Scheffer et al. 2001) and are being adopted as policy throughout the U.S. (USDA 2010). Our goal was to create STMs to inform land management decision making and improve resilience of rangeland social-ecological systems. STM development occurred in four steps with four distinct sets of models (Fig. 1): (1) local knowledge elicitation using semistructured interviews; (2) ecological data collection using an observational study; (3) model integration using participatory workshops; and (4) model simplification upon review of the literature by a multidisciplinary team.

\section{Knowledge integration}

Different knowledge types had strengths and weaknesses (Table 3) but were ultimately complementary in creating STMs for managing ecosystem resilience, as others have also suggested (Walker et al. 2002, Roux et al. 2006, Raymond et al. 2010). LK encompassed a relatively long time frame, informed understanding of management practices, identified local management concerns, and provided information at a local scale (Knapp and Fernandez-Gimenez 2009, Berkes 2010). Including local knowledge also had the cobenefits of increasing awareness and buy-in of potential users (Prell et al. 2007). ED collected in an observational study provided more information about plant species and soils, and increased the specificity to the different land types (Bestelmeyer et al. 2009, Kachergis et al. 2011, 2012). However, even data-driven models included choices about assumptions, indicators, and analysis methods that affected the final STM. Integrating the ED and LK models in a workshop (IN) allowed participants to draw upon and reconcile both types of knowledge and resulted in the most complex models (Knapp et al. 2011a). This integration process generated new understanding, revealed assumptions, and identified uncertainties (Tables 1 and 2; Fairweather 2010). Simplifying the models through multidisciplinary team discussion and further literature review (SI) resulted in a model with fewer states and more specific transitions and probabilities, but may not represent the complexity of the real world. The process of sharing knowledge is also a process about sharing language; the LK, 
IN, and SI were learning experiences and allowed for more effective communication among managers, local residents, and scientists from a variety of disciplines (Knapp et al. 2011a). Multiple types of knowledge, as in the IN, are needed to create tools that are broadly credible and useful in land management (Cash et al. 2003, Knapp et al. 2011b).

Despite much agreement among different types of knowledge, several uncertainties remained throughout the STM building process. One key uncertainty centered around interpretation of ecological theory: differentiating states from communities, e.g., sagebrush shrublands characterized by western wheatgrass (Briske et al. 2008, Scheffer 2009). There may be two, interrelated reasons for this: (1) a lack of consensus on the definition of thresholds (Knapp et al. 2011b) and (2) in LK and IN, the difficulty of communicating complex theoretical concepts in a few hours' interaction. In LK, Knapp and Fernandez-Gimenez (2009:516) defined a threshold as "a boundary recognized by managers beyond which it is difficult to regain the former productive potential of the land." With IN, we presented a technical definition based on the STM literature (Stringham et al. 2003:109): An irreversible change between states, "such that one or more primary ecological processes has been irreversibly changed and must be actively restored before a return to a previous state is possible." However, we do not know whether participants felt that all of the characteristics of a threshold were met. Some IN and SI states more closely resemble a "narrow" interpretation of states, approximating seral stages or phases, rather than a "broader" interpretation of states, as separated by thresholds (Stringham et al. 2003, Briske et al. 2008). ED approaches can provide more clarity about differences in process (Stringham et al. 2003, Petersen et al. 2009, Kachergis et al. 2011), but still rely on assumptions to identify thresholds, e.g., space-fortime substitution. Ultimately, long-term data and experiments provide the strongest evidence to differentiate states from communities (e.g., Allen-Diaz and Bartolome 1998, Firn et al. 2010), and should be included in the STM development process when they are available. When they are not, setting aside time to ask specific theory-based questions (e.g., Scheffer and Carpenter 2003) in interviews and workshops may provide stronger evidence of thresholds. Resilience management tools that are less tied to ecological theory than STMs may avoid this issue.

In addition to theoretical uncertainty, the STM-building process highlighted several disagreements between ecological data, land managers, and community members, thus clarifying where mental models aligned and where they conflicted. Some disagreements resulted from different perspectives on ecosystem dynamics. For example, although ecologists focused on species and processes, ranchers identified a "weedy" state that is important for management even though invasive plant cover is low (Knapp and Fernandez-Gimenez 2009). Similarly, although economists initially sought to elicit transition probabilities on a one-year time-step, because many land managers make decisions on an annual basis, the research team lengthened that time to three years because sagebrush ecosystems change slowly (Dalgleish et al. 2011). Values also influence how different people understand and interpret landscapes, and are embodied in the language used in STMs. For example, local residents used terms such as "degraded" and "improved" to describe states, whereas ecologists described states using plant species. Although the value-laden terms used by local residents may be less precise, these descriptors give valuable information about the social drivers and impacts of vegetation change, just as species provide valuable information about the ecological function of an area. Disagreements may be seen as a formidable part of any participatory effort to build models for managing resilience, but ultimately can help to create a shared understanding of the system and improve models (Walker et al. 2002). Therefore, it is important to maintain a clear, fair process for validating and integrating different types of knowledge to prevent disagreements from derailing the effort. For example, scientific knowledge can be validated through statistical procedures that measure certainty, peer review, and replication; local knowledge can be validated through comparisons among different sources; and hybrid forms of knowledge can be investigated through cooperative efforts among multiple knowledge holders.

Like Raymond et al. (2010), we suggest that future efforts to build tools for resilience management should move beyond debate surrounding different types of knowledge to focus on the process of learning from one another and creating hybrid forms of knowledge. Model updating and validation was an iterative process for our team (Bellamy and Brown 1994), involving increasing dialogue between different types of knowledge holders (Fig. 3). Many of the benefits of making and updating STMs flowed directly from the knowledge integration activities (IN and SI). By the last step of the process, previously forged connections allowed model builders to consult an increasingly broad group of knowledge holders to create the SI (Fig. 3). For example, a wildlife biologist asked many meaningful questions about the STMs that resulted in further clarification; ecologists phoned ranchers to ask for insight in interpreting ecological data. Importantly, we do not view the SI as the most accurate model, but the model that has accumulated the most evidence behind it, thus far. Like all conceptual models for managing resilience, this model could and should be tested through adaptive management and additional field data and management experience. A key step in improving the current multiagency STM building processes is to create a mechanism by which new sources of information can be easily and readily incorporated (Knapp et al. 2011b), and others have also suggested mechanisms for incorporating multiple types of information for resilience management (Walker et al. 2002, Roux et al. 2006). As in this study, different types of knowledge can be validated via triangulation, where claims with greater support, i.e., similar observations or 
Fig. 3. Contribution of different knowledge sources at different steps of the multidisciplinary state and transition model development process. At each step, an increasingly broad group of knowledge sources contributed to the process.

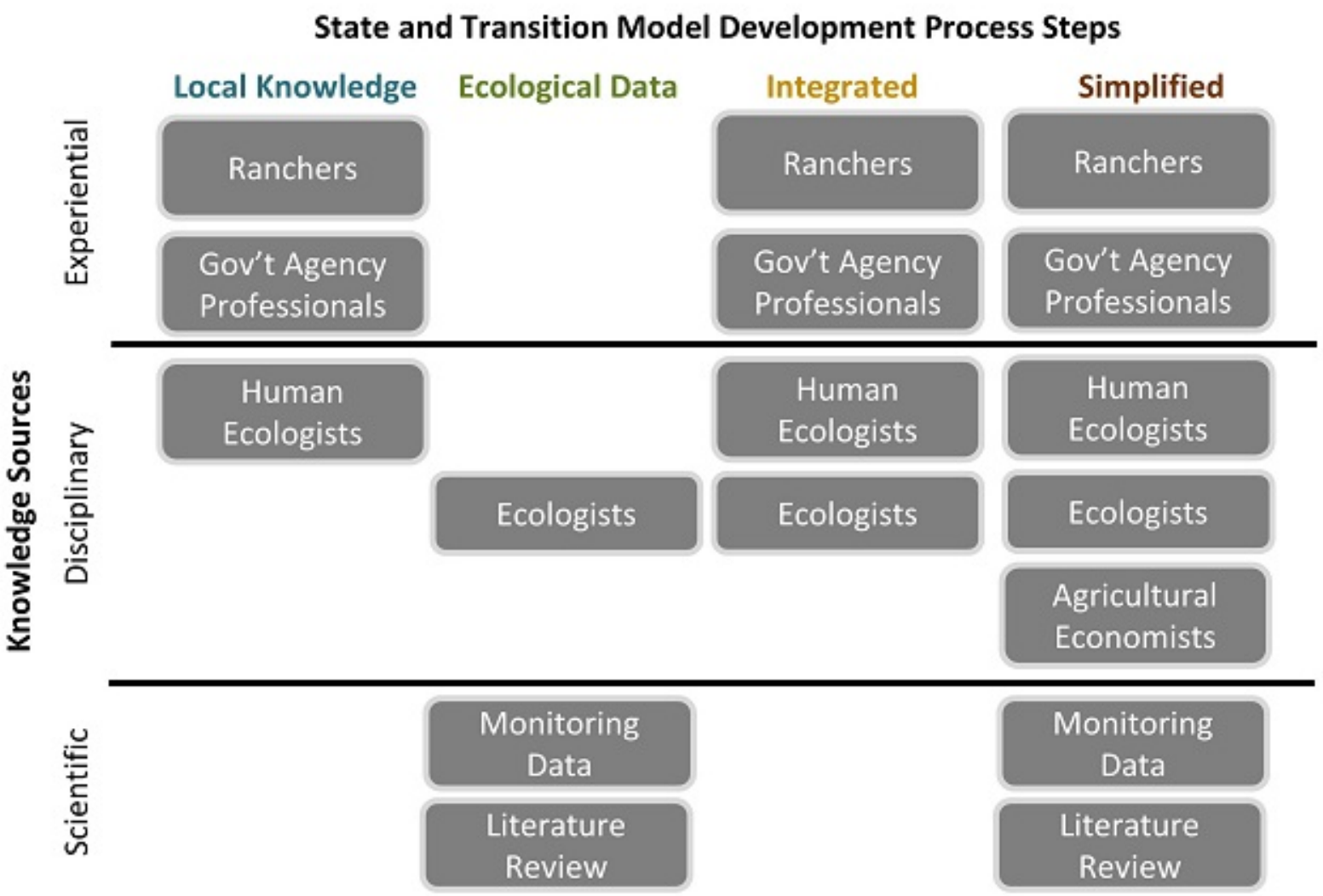

correspondence with data, suggest more credible information, while claims with fewer observations suggest places where more observations are necessary.

\section{Utility of products}

STMs can inform resilience management by providing an overview of ecosystem structure-function relationships and how these relationships can be influenced by natural and human-caused perturbations (Briske et al. 2008). Each step in our process created a different STM with different applications for resilience management (Table 3). Integrating knowledge resulted in complex models, which represent a wide array of knowledge and allow for comparison and dialogue between different stakeholders (Knapp et al. 2011a). However, the simple SI models that resulted from multidisciplinary team review and literature review were better for creating quantitative STMs. Development of the economic model that explores trade-offs in ecosystem services (Hibbs 2011, Ritten et al. 2011, Pritchett et al. 2012) would have been intractable with more complex STMs, and consultation with economists caused us to initiate the SI process. The tension between realism and usability is well-known in mathematical modeling, as captured by the saying "All models are wrong, but some are useful." Ironically, other rangeland scientists have advocated more complex and biologically realistic STMs, whereas land managers have argued for simpler models that are easier to use (Knapp et al. 2011b). Rather than creating different models for different purposes, we suggest that complex models may be better for representing the variety of dynamics that could occur in land management, while subsets of those models, like the SI, may be useful for particular applications.

The STMs identify several key processes influencing ecosystem dynamics and resilience in the Elkhead Watershed. The fundamental process on both ecological sites was plant population growth, particularly species establishment and interspecific competition. Management practices and disturbances influenced dynamics of key species such as sagebrush, herbaceous plants, and weeds and their interactions with each other. Dominance of any of these species as well as a mix of native plants species were seen as relatively resilient conditions. In addition, soil erosion was an important process particularly on the Claypan ecological site, where clayey soil texture may limit infiltration and promote surface runoff during storms (Kachergis et al. 2012). According to transition probabilities (SI), Claypan eroding sagebrush steppe was the most resilient state of all. 
The STM development effort also generated hypotheses about rangeland ecosystem dynamics and resilience that could be tested by future adaptive management and research. Here are several hypotheses, supported by multiple types of knowledge, involving the state with the lowest forage production on each type of land:

1. Claypan eroding sagebrush steppe: The transition to this state is caused by heavy grazing, drought, and/or fire, which decrease herbaceous plant cover and increase erosion. The transition back to the diverse sagebrush steppe state is caused by reduction in grazing and favorable precipitation, but is very unlikely.

2. Mountain Loam dense or eroding sagebrush steppe: The transition to this state is caused by heavy grazing and/or drought that reduces herbaceous plant cover, allowing sagebrush to become dominant and competitively exclude re-establishment of herbaceous plants. The transition back to the diverse sagebrush steppe state requires shrub disturbance in addition to favorable precipitation and reduced grazing, and is fairly likely given these conditions.

Similarly, here are two sets of competing hypothesis from different knowledge types that may be important for resolving uncertainty about rangeland ecosystem dynamics and resilience in the future:

1. Sagebrush/western wheatgrass shrublands: Based on SI, the transition to this state is driven by weather patterns (wetter years) and moderate grazing, which encourage western wheatgrass population growth on both ecological sites. However, based on ED, occurrence of this state is also related to variability within both ecological sites, i.e., soils with higher surface clay content.

2. Weedy sagebrush steppe: LK suggests that the transition to this state is related to drought and/or heavy grazing by wildlife or cattle, which reduce native plant populations and allow weed populations to establish and grow. IN adds fire, recreation, and improper reclamation as possible transition triggers, with weed seed dispersal as another important mechanism. IN and LK suggest that lowered grazing, favorable precipitation, and/or treatment of weeds reverse this transition. ED suggests that this is a community within Native Sagebrush Steppe rather than a state because weeds do not often become dominant where they occur in this region.

These hypotheses may be fruitful for adaptive management and future learning (Holling 1978, Grantham et al. 2010). For example, restoration treatments could be applied to sites already in the Claypan eroding sagebrush steppe and Mountain Loam dense/eroding sagebrush steppe states, to determine pathways of recovery. Similarly, sagebrush/western wheatgrass shrublands could be subjected to different grazing pressures and monitored over time in conjunction with rainfall, to determine whether this shift is temporary (community) or persistent (state). STMs created with input and monitoring data collected by land managers may increase the probability that STMs will affect rangeland decision making at a local scale (Danielsen et al. 2010).

\section{CONCLUSION}

We conclude that multidisciplinary development of state and transition models has great potential for improving our understanding of dynamics and managing resilience of rangeland ecosystems. Approaches that integrate different types of information result in more credible tools that can be applied in more diverse situations, e.g., economic model (Ritten et al. 2011, Pritchett et al. 2012). Participatory model development is complex and can be difficult to document, but documentation is important for the credibility of the models. In particular, documenting uncertainty and disagreement enables future learning through adaptive management.

Based on this work, we imagine a streamlined participatory state-and-transition model development process that integrates multiple types of information, which could be adapted to building other tools for managing resilience. Our approach is similar to that proposed by Bestelmeyer et al. (2009), but with an increased emphasis on local knowledge and adaptive management, in addition to collection of ecological inventory data. The proposed steps of this process are:

\section{Assemble a draft STM from what is known}

This includes literature review as well as searching for available data including remote sensing, historical records, and monitoring data. Depending on key uncertainties/ hypotheses identified by future steps, additional data analysis and synthesis and efforts may be ongoing throughout the process.

Organize a modeling workshop to integrate the draft STM with local knowledge

Invite diverse local knowledge holders to attend, including individuals with experiential, disciplinary, and scientific knowledge. In addition to cataloguing states and transitions (e.g., Knapp et al. 2011a), add activities that specifically (1) differentiate states from communities and (2) identify uncertainties and testable hypotheses.

\section{Conduct an observational study designed to address key uncertainties and hypotheses}

Work with local ranchers and land management agencies to identify management history and locations for sampling, and target specific states and transitions that have important implications for management and/or high uncertainty. Present data and preliminary analysis to the community to update the STMs and identify remaining uncertainties. 


\section{Initiate adaptive management}

Work with local ranchers and land management agencies to design a series of adaptive management experiments to test hypotheses. This will involve baseline monitoring, implementing management practices, additional monitoring, and evaluating the outcomes. The STM should be updated as more is learned, through a continuing participatory process involving multiple stakeholders.

Responses to this article can be read online at: http://www.ecologyandsociety.org/issues/responses. $\mathrm{php} / 5805$

\section{Acknowledgments:}

We would like to acknowledge research participants from the Elkhead watershed and beyond whose knowledge and insight made this project possible. Funding was provided by the USDA National Institute of Food and Agriculture Managed Ecosystems Program (COL0-2008-00725), a Natural Resource Conservation Service Colorado Conservation Innovation Grant (AG-8BO5-A-6-33), and the Colorado Agricultural Experiment Station (COL00698).

\section{LITERATURE CITED}

Abel, N., H. Ross, A. Herbert, M. Manning, P. Walker, and H. Wheeler. 1998. Mental models and communication in agriculture. Rural Industries Research and Development Corporation Publication No 98/140. Barton, Australia.

Agrawal, A. 1995. Indigenous and scientific knowledge: some critical comments. Indigenous Knowledge and Development Monitor 3(3). [online] URL: http://app.iss.nl/ikdm/ikdm/ ikdm/3-3/articles/agrawal.html

Allen-Diaz, B., and J. W. Bartolome. 1998. Sagebrush-grass vegetation dynamics: comparing classical and state-transition models. Ecological Applications 8(3):795-804.

Bashari, H., C. Smith, and O. J. H. Bosch. 2008. Developing decision support tools for rangeland management by combining state and transition models and Bayesian belief networks. Agricultural Systems 99(1):23-34. http://dx.doi. org/10.1016/j.agsy.2008.09.003

Bellamy, J. A., and J. R. Brown. 1994. State and transition models for rangelands. 7. Building a state and transition model for management and research on rangelands. Tropical Grasslands 28(4):247-255.

Berkes, F. 2010. Devolution of environment and resources governance: trends and future. Environmental Conservation 37:489-500. http://dx.doi.org/10.1017/S037689291000072X
Berkes, F., J. Colding, and C. Folke. 2000. Rediscovery of traditional ecological knowledge as adaptive management. Ecological Applications 10(5):1251-1262. http://dx.doi. org/10.1890/1051-0761(2000)010[1251:ROTEKA]2.0.CO;2

Bestelmeyer, B. T., J. R. Brown, K. M. Havstad, R. Alexander, G. Chavez, and J. E. Herrick. 2003. Development and use of state-and-transition models for rangelands. Journal of Range Management 56(2):114-126. http://dx.doi.org/10.2307/4003894

Bestelmeyer, B. T., A. J. Tugel, G. L. Peacock Jr, D. G. Robinett, P. L. Shaver, J. R. Brown, J. E. Herrick, H. Sanchez, and K. M. Havstad. 2009. State-and-transition models for heterogeneous landscapes: a strategy for development and application. Rangeland Ecology \& Management 62(1):1-15. http://dx.doi.org/10.2111/08-146

Briske, D. D., B. T. Bestelmeyer, T. K. Stringham, and P. L. Shaver. 2008. Recommendations for development of resilience-based state-and-transition models. Rangeland Ecology \& Management 61(4):359-367. http://dx.doi. org/10.2111/07-051.1

Cagney, J., E. Bainter, B. Budd, T. Christiansen, V. Herren, M. Holloran, B. Rashford, M. Smith, and J. Williams. 2010. Grazing influence, objective development, and management in Wyoming's Greater Sage-grouse habitat. University of Wyoming Extension, Laramie, Wyoming, USA.

Cain, J. 2001. Planning improvements in natural resources management: guidelines for using Bayesian networks to support the planning and management of development programmes in the water sector and beyond. Center for Ecology and Hydrology, Wallingford, UK.

Cash, D. W., W. N. Adger, F. Berkes, P. Garden, L. Lebel, P. Olsson, L. Pritchard, and O. Young. 2006. Scale and crossscale dynamics: governance and information in a multilevel world. Ecology and Society 11(2): 8. [online] URL: http:// www.ecologyandsociety.org/vol11/iss $2 / \operatorname{art} 8 /$

Cash, D. W., W. C. Clark, F. Alcock, N. M. Dickson, N. Eckley, D. H. Guston, J. Jäger, and R. B. Mitchell. 2003. Knowledge systems for sustainable development. Proceedings of the National Academy of Sciences of the United States of America 100(14):8086-8091. http://dx.doi.org/10.1073/ pnas. 1231332100

Clemen, R. T., and R. L. Winkler. 1999. Combining probability distributions from experts in risk analysis. Risk Analysis 19(2):187-203. http://dx.doi.org/10.1111/j.1539-6924.1999. tb00399.x

Danielsen, F., N. D. Burgess, P. M. Jensen, and K. PirhoferWalzl. 2010. Environmental monitoring: the scale and speed of implementation varies according to the degree of peoples involvement. Journal of Applied Ecology 47(6):1166-1168. http://dx.doi.org/10.1111/j.1365-2664.2010.01874.x 
Dalgleish, H. J., D. N. Koons, M. B. Hooten, C. A. Moffet, and P. B. Adler. 2011. Climate influences the demography of three dominant sagebrush steppe plants. Ecology 92(1):75-85. http://dx.doi.org/10.1890/10-0780.1

Dewalt, B. R. 1994. Using indigenous knowledge to improve agriculture and natural resource management. Human Organization 53(2):123-131.

Duniway, M. C., B. T. Bestelmeyer, and A. Tugel. 2010. Soil processes and properties that distinguish ecological sites and states. Rangelands 32(6):9-15. http://dx.doi.org/10.2111/ RANGELANDS-D-10-00090.1

Eshuis, J., and M. Stuiver. 2005. Learning in context through conflict and alignment: farmers and scientists in search of sustainable agriculture. Agriculture and Human Values 22 (2):137-148. http://dx.doi.org/10.1007/s10460-004-8274-0

Fairweather, J. 2010. Farmer models of socio-ecologic systems: Application of causal mapping across multiple locations. Ecological Modelling 221(3):555-562. http://dx. doi.org/10.1016/j.ecolmodel.2009.10.026

Fazey, I., K. Proust, B. Newell, B. Johnson, and J. A. Fazey. 2006. Eliciting the implicit knowledge and perceptions of onground conservation managers of the Macquarie Marshes. Ecology and Society 11(1): 25. [online] URL: http://www. ecologyandsociety.org/vol11/iss1/art25/

Fernandez-Gimenez, M. E., H. P. Huntington, and K. J. Frost. 2007. Integration or co-optation? Traditional knowledge and science in the Alaska Beluga Whale Committee. Environmental Conservation 33(4):306-315. http://dx.doi. org/10.1017/S0376892906003420

Firn, J., A. P. N. House, and Y. M. Buckley. 2010. Alternative states models provide an effective framework for invasive species control and restoration of native communities. Journal of Applied Ecology 47(1):96-105. http://dx.doi.org/10.1111/ j.1365-2664.2009.01741.x

Flora, C. B. 1992. Reconstructing agriculture: the case for local knowledge. Rural Sociology 57(1):92-97. http://dx.doi. org/10.1111/j.1549-0831.1992.tb00459.x

Fortmann, L., and H. Ballard. 2011. Sciences, knowledges, and the practice of forestry. European Journal of Forest Research 130(3):467-477. http://dx.doi.org/10.1007/s10342-009-0334Y

Grantham, H. S., M. Bode, E. McDonald-Madden, E. T. Game, A. T. Knight, and H. P. Possingham. 2010. Effective conservation planning requires learning and adaptation. Frontiers in Ecology and the Environment 8(8):431-437. http://dx.doi.org/10.1890/080151

Heemskerk, M., K. Wilson, and M. Pavao-Zuckerman. 2003. Conceptual models as tools for communication across disciplines. Conservation Ecology 7(3): 8. [online] URL: http://www.ecologyandsociety.org/vol7/iss3/art8/
Hibbs, W. 2011. Assessing wildlife habitat suitability for ecological sites and state and transition models. Thesis. Colorado State University, Fort Collins, Colorado, USA.

Hobbs, R. J., and K. N. Suding, editors. 2009. New models for ecosystem dynamics and restoration. Island Press, Washington, D.C., USA.

Holling, C. S. 1973. Resilience and stability of ecological systems. Annual Review of Ecology and Systematics 4:1-23. http://dx.doi.org/10.1146/annurev.es.04.110173.000245

Holling, C. S. 1978. Adaptive environmental assessment and management. International Institute for Applied Systems Analysis, New York, New York, USA.

Jackson, L. J., A. S. Trebitz, and K. L. Cottingham. 2000. An introduction to the practice of ecological modeling. BioScience 50(8):694-706. http://dx.doi.org/10.1641/0006-3568 (2000)050[0694:AITTPO]2.0.CO;2

Jones, N. A., H. Ross, T. Lynam, P. Perez, and A. Leitch. 2011. Mental models: an interdisciplinary synthesis of theory and methods. Ecology and Society 16(1): 46. [online] URL: http:// www.ecologyandsociety.org/vol16/iss1/art46/

Kachergis, E., M. E. Fernandez-Gimenez, and M. E. Rocca. 2012. Differences in plant species composition as evidence of alternate states in the sagebrush steppe. Rangeland Ecology \& Management 65(5):486-497. http://dx.doi.org/10.2111/ REM-D-11-00137.1

Kachergis, E., M. E. Rocca, and M. E. Fernandez-Gimenez. 2011. Indicators of ecosystem function identify alternate states in the sagebrush steppe. Ecological Applications 21 (7):2781-2792. http://dx.doi.org/10.1890/10-2182.1

Knapp, C. N., and M. E. Fernandez-Gimenez. 2009. Understanding change: integrating rancher knowledge into state-and-transition models. Rangeland Ecology \& Management 62(6):510-521. http://dx.doi.org/10.2111/08-176.1

Knapp, C. N., M. E. Fernandez-Gimenez, D. D. Briske, B. T. Bestelmeyer, and X. B. Wu. 2011b. An assessment of stateand-transition models: perceptions following two decades of development and implementation. Rangeland Ecology \& Management 64(6):598-606. http://dx.doi.org/10.2111/REMD-10-00188.1

Knapp, C. N., M. Fernandez-Gimenez, E. Kachergis, and A. Rudeen. 2011a. Using participatory workshops to integrate state-and-transition models created with local knowledge and ecological data. Rangeland Ecology \& Management 64 (2):158-170. http://dx.doi.org/10.2111/REM-D-10-00047.1

McCarthy, M. A. 2007. Subjective priors. Pages 225-243 in Bayesian methods for ecology. Cambridge University Press, Cambridge, UK. http://dx.doi.org/10.1017/CBO9780511802454.012

Patel, M., K. Kok, and D. S. Rothman. 2007. Participatory scenario construction in land use analysis: an insight into the 
experiences created by stakeholder involvement in the Northern Mediterranean. Land Use Policy 24(3):546-561. http://dx.doi.org/10.1016/j.landusepol.2006.02.005

Pellant, M., P. Shaver, D. Pyke, and J. Herrick. 2005. Interpreting indicators of rangeland health, version 4. Technical Reference 1734-6. U.S. Department of the Interior, Bureau of Land Management, National Science and Technology Center, Denver, Colorado, USA.

Peloquin, C., and F. Berkes. 2009. Local knowledge, subsistence harvests, and social-ecological complexity in James Bay. Human Ecology 37(5):533-545. http://dx.doi. org/10.1007/s10745-009-9255-0

Petersen, S. L., T. K. Stringham, and B. A. Roundy. 2009. A process-based application of state-and-transition models: a case study of Western Juniper (Juniperus occidentalis) encroachment. Rangeland Ecology \& Management 62 (2):186-192. http://dx.doi.org/10.2111/06-171.1

Plummer, R., and D. Armitage. 2007. A resilience-based framework for evaluating adaptive co-management: linking ecology, economics and society in a complex world. Ecological Economics 61(1):62-74. http://dx.doi.org/10.1016/ j.ecolecon.2006.09.025

Pritchett, J. G., E. Kachergis, J. Parsons, M. E. FernandezGimenez, and J. P. Ritten. 2012. Home on a transitioning range: a ranch simulation game demonstrating STMs. Rangelands 34(3):53-59. http://dx.doi.org/10.2111/1551-50$\underline{1 X-34.3 .53}$

Prell, C., K. Hubacek, M. Reed, C. Quinn, N. Jin, J. Holden, T. Burt, M. Kirby, and J. Sendzimir. 2007. If you have a hammer everything looks like a nail: traditional versus participatory model building. Interdisciplinary Science Reviews 32(3):263-282. http://dx.doi.org/10.1179/030801807X211720

Raymond, C. M., I. Fazey, M. S. Reed, L. C. Stringer, G. M. Robinson, and A. C. Evely. 2010. Integrating local and scientific knowledge for environmental management. Journal of Environmental Management 91:1766-1777. http://dx.doi. org/10.1016/j.jenvman.2010.03.023

Ritten, J. P., M. E. Fernandez-Gimenez, E. Kachergis, W. Hibbs, and J. G. Pritchett. 2011. Do livestock and ecosystem services compete? A state-and-transition approach. Proceedings of the Range Beef Cow Symposium, November 29-December 1, 2011, Mitchell, Nebraska, USA.

Roux, D. J., K. H. Rogers, H. C. Biggs, P. J. Ashton, and A. Sergeant. 2006. Bridging the science-management divide: moving from unidirectional knowledge transfer to knowledge interfacing and sharing. Ecology and Society 11(1): 4. [online] URL: http://www.ecologyandsociety.org/vol11/iss1/art4/

Scheffer, M. 2009. Critical transitions in nature and society. Princeton University Press, Princeton, New Jersey, USA.
Scheffer, M., and S. R. Carpenter. 2003. Catastrophic regime shifts in ecosystems: linking theory to observation. Trends in Ecology \& Evolution 18(12):648-656. http://dx.doi. org/10.1016/j.tree.2003.09.002

Scheffer, M., S. Carpenter, J. A. Foley, C. Folke, and B. Walker. 2001. Catastrophic shifts in ecosystems. Nature 413:591-596. http://dx.doi.org/10.1038/35098000

Stringham, T. K., W. C. Krueger, and P. L. Shaver. 2003. State and transition modeling: an ecological process approach. Journal of Range Management 56(2):106-113. http://dx.doi. org $/ 10.2307 / 4003893$

Suding, K. N., and R. J. Hobbs. 2009. Threshold models in restoration and conservation: a developing framework. Trends in Ecology \& Evolution 24(5):271-279. http://dx.doi. org/10.1016/j.tree.2008.11.012

U.S. Department of Agriculture (USDA). 2010. Rangeland interagency site manual: memorandum of understanding. United States Government, Washington, D.C, USA.

Walker, B., S. Carpenter, J. Anderies, N. Abel, G. S. Cumming, M. Janssen, L. Lebel, J. Norberg, G. D. Peterson, and R. Pritchard. 2002. Resilience management in socialecological systems: a working hypothesis for a participatory approach. Conservation Ecology 6(1): 14. [online] URL: http://www.ecologyandsociety.org/vol6/iss1/art14/

Walters, C. J., and C. S. Holling. 1990. Large-scale management experiments and learning by doing. Ecology 71 (6):2060-2068. http://dx.doi.org/10.2307/1938620

Westoby, M., B. Walker, and I. Noy-Meir. 1989. Opportunistic management for rangelands not at equilibrium. Journal of Range Management 42(4):266-274. http://dx.doi. org/10.2307/3899492

Zweig, C. L., and W. M. Kitchens. 2009. Multi-state succession in wetlands: a novel use of state and transition models. Ecology 90(7):1900-1909. http://dx.doi.org/10.1890/08-1392.1 